В. Артемов, доктор педагогічних наук, доцент Національна академія Служби безпеки України

В. Серіков, кандидат педагогічних наук, старший науковий співробітник,

\title{
РОЗВИТОК ПЕДАГОГІЧНОЇ МАЙСТЕРНОСТІ ВИКЛАДАЧА ВИЩОГО НАВЧАЛЬНОГО ЗАКЛАДУ ЗІ СПЕЦИФІЧНИМИ УМОВАМИ НАВЧАННЯ
}

\begin{abstract}
У статі здійснено спробу дослідити проблеми розвитку педагогічної майстерності викладача вищого військового навчального закладу зі специфічними умовами навчання. Проблема розвитку педагогічної майстерності викладача ВНЗ зі специффічними умовами навчання полягає у детальному вивченні структури його педагогічної компетентності $i$ відповідно у створенні, розробиі й подальшому впровадженню в систему військової освіти механізмів підготовки викладача-майстра - акмепрофесіонала, якому властива самоорганізація і саморозвиток під впливом певних акмеологічних та деонтологічних факторів, умов і ресурсів.
\end{abstract}

Ключові слова: педагогічна майстерність; професійної готовності; професійна компетентність; метакомпетентність; предметна компетентність; компетентнісноорієнтований підхід; кластерний аналіз.

Постановка проблеми. В наш буремний час відбувається переосмисленням соціальної і професійної місії викладачів вищих навчальних закладів із специфічними умовами навчання, яке викликано змінами у військово-політичному та соціально-економічному стані України. Вищі навчальні заклади із специфічними умовами навчання (вищі військові навчальні заклади), відповідно до Закону України «Про вищу освіту» від 1.07 .2014 р. [3] здійснюють на певних рівнях вищої освіти підготовку курсантів (слухачів, студентів), ад’юнктів для подальшої служби на посадах офіцерського (сержантського, старшинського) або начальницького складу 3 метою задоволення потреб Міністерства внутрішніх справ України, Національної поліції, Збройних Сил України, інших утворених відповідно до законів України військових формувань, центральних органів виконавчої влади із спеціальним статусом, Служби безпеки України, Служби зовнішньої розвідки України, центрального органу виконавчої влади, що реалізує державну політику у сфері охорони державного кордону, центрального органу виконавчої влади, який забезпечує формування та реалізує державну політику у сфері цивільного захисту.

Специфіка цього виду вищих навчальних закладів у сучасних військовополітичних та суспільно-економічних умовах України вимагає пошуку поновлених шляхів удосконалення педагогічної майстерності викладачів цієї ланки, специфіка якої у нових умовах, нажаль, не отримала належного висвітлення.

Аналіз основних досліджень і публікацій. Незважаючи на значну кількість досліджень, присвячених проблемі розвитку педагогічної майстерності викладачів вищого навчального закладу, в тому числі i військового, (І.А. Зязюн [7], В.В. Ягупов [8], С.А. Калашникова, Т.В. Мухлаева [2], П.І Матвієнко, О.О. Новак [1], Метешкін К.О. [5], Маркова А.К. [6], Сидоренко В.В. [4] та ін.) і досі відсутнє фундаментальне теоретико-методологічне дослідження у якому б грунтовно було дослідження 
розвитку педагогічної майстерності викладачів ВН3 зі специфічними умовами навчання.

Мета статті полягає у дослідженні проблем розвитку педагогічної майстерності викладача вищого військового навчального закладу (ВН3 зі специфічними умовами навчання).

Виклад основного матеріалу. Розвиток професійної готовності майбутнього військовослужбовця, співробітника спеціальних органів і служб України становить багатовимірний циклічний процес якісних змін 3 урахуванням парадигмальних позицій педагогічної науки, на основі використання новітніх підходів, моделей і форм підвищення кваліфікації, що грунтуються на принципах неперервності, гнучкості, відкритості, диференційованості, трансформації у сферу освітніх послуг. Новим концептуальним орієнтиром модернізації системи педагогічної освіти у вищому військовому навчальному закладі зі спеціальними умовами навчання є компетентнісно-орієнтований підхід, що забезпечує цілісність, неперервність зростання викладача-військовослужбовця [8] за науководослідницькою, професіографічною та освітньо-персонологічною (особистісною) складовими [1], здетерміновує вдосконалення загальнокультурного, фахово-кваліфікаційного і функціонального компонентів професійної компетентності [2].

Упровадження розглядуваного методологічного підходу в систему військової освіти означає переорієнтацію викладача, з процесу на результат у діяльнісному вимірі, підсилення практичної спрямованості курсової підготовки, акцентування уваги на новій якості професійно-педагогічної дії. Отже, компетентнісно-орієнтований підхід $\epsilon$ необхідною умовою для створення диференційованого акмеологічного професійного простору, який вимагає розробки диференційованих програм розвитку педагогічної майстерності викладача вищого військового навчального закладу (ВН3 зі специфічними умовами навчання) [3], формування його самобутньої професійної позиції.

Дієвий шлях підвищення ефективності професійної компетентності викладача - це, безумовно, розвиток його педагогічної майстерності. Професійна компетентність $€$ підвалиною педагогічної майстерності, оскільки спрямованість і професійні знання становлять той кістяк високого професіоналізму в діяльності, який забезпечує цілісність системи, що само організується ) [4].

Співвідносячи поняття «компетентність», «готовність до діяльності», «професіоналізм» і «майстерність» можемо визначити рівневу інтеграцію, причому професійна компетентність викладача-військовослужбовця інтерпретується базовим рівнем, на основі якого формується готовність фахівця до професійної діяльності, його професіоналізм і педагогічна майстерність.

Професійну компетентність викладача ВНЗ зі специфічними умовами навчання визначаємо як інтегральну характеристику особистості, що включає комплексне поєднання грунтовних, систематичних знань, професійно- 
педагогічних ціннісних орієнтацій, акмеологічних та деонтологічних інваріантів, зокрема спеціальних педагогічних здібностей (оперативних, комунікативних, моральних, психологічних, емоційно-творчих, артистичних, етичних тощо), властивостей, характерологічних ознак, особистісних якостей (темпераменту, інтелекту, нахилів, переконань, потреб, установок) тощо, акмеологічної професійної позиції, які забезпечують розвиток педагогічної майстерності викладача протягом всього життя, готовність здійснювати високопродуктивну професійно-педагогічну діяльність у сучасних умовах.

Професійна компетентність викладача ВН3 зі специфічними умовами навчання виступає складовою професіоналізму діяльності і професіоналізму особистості, тобто інтегрованим показником діяльнісної та індивідуальноособистісної сутності викладача, для якого важливо в умовах військової освіти не стільки оволодіти системою професійно-особистісних знань, умінь і навичок, скільки вміти майстерно мобілізувати їх у певній ситуації для творчо-продуктивного розв'язання завдань на професійному рівні.

Професійно-педагогічна компетентність викладача-військовослужбовця визначається обсягом компетенцій, є результатом їх набуття на всіх етапах навчання. Під компетенціями розуміємо коло повноважень викладача у професійно-педагогічній, індивідуально-особистісній і мотиваційній сферах діяльності, що визначається завданнями такої специфічної освітньої галузі, якою $є$ військова освіта, ii нормативно-правовою базою, та спрямовують викладача на вироблення нової якості професійно-педагогічної дії, індивідуально-творчого стилю роботи, продуктивного способу досягнення мети.

Грунтовне вивчення професійно-педагогічної компетентності викладача видається можливим за використання кластерного аналізу професійно значущих компетентностей і компетенцій у їх ієрархічному взаємозв'язку і взаємозумовленості. Багатозначною лексемою «кластер» (від англ. скупчення) послуговуємося на позначення групи тісно пов'язаних один 3 одним об'єктів із спільними ознаками, об'єднання окремих елементів в одне ціле для виконання певної функції чи реалізації мети. Використовуємий метод кластерного аналізу дозволяє згрупувати компоненти професійнопедагогічної компетентності викладача-військовослужбовця в ієрархічні рівні (метапредметні компетентності, предметні компетентності, компетенції) за певною сферою, зокрема 1) компетентності i/або компетенції професійно-педагогічної діяльності, 2) компетентності i/або компетенції професійно-педагогічного спілкування та 3) компетентності i/або компетенції в реалізації особистості викладача-майстра [4].

Відомий акмеолог А.А. Маркова [5] зазначає, що професіоналізм (інтегральна психологічна характеристика людини праці, за якої трудова діяльність здійснюється на рівні високих зразків) i професійна компетентність включають професійну діяльність, професійне спілкування та особистість професіонала.

Своєрідний базис, основу професійно-педагогічної компетентності викладача військового ВНЗ становлять метакомпетентності або 
метапредметні компетентності, що є іiі ключовими, надпредметними, поліфункціональними, інваріантними структурними компонентами, які складають суспільно визначений комплекс універсальних знань, умінь, ставлень, цінностей для компетентного вирішення міжпредметного кола проблем, забезпечують професійний розвиток фахівця, дають змогу особистості ефективно брати участь у багатьох соціальних сферах і сприяють особистому успіхові. До основоположних характеристик метакомпетентностей зараховуємо такі: наявність особистісних смислів, мотивації, спроможність і готовність викладача до професійно-педагогічної діяльності, ціннісну зорієнтованість, ставлення; процесуальність, результативність, системність [6]. Метапредметні компетентності інтегрують предметні компетентності, що охоплюють вузькоспеціалізовані знання предметів спецдисциплін, професійно значущі предметні навички та характеризують його професійно-педагогічну діяльність.

Для створення диференційованого акмеологічного професійного простору в системі військової освіти, визначення ефективних шляхів розвитку педагогічної майстерності викладача військового ВНЗ детальніше розглянемо традиційні та інноваційні складові професійно-педагогічної компетентності викладача-військовослужбовця, ураховуючи та виважено описуючи на кожному ієрархічному рівні структури три обов'язкові сфери, зокрема професійно-педагогічної діяльності, професійного спілкування та особистості викладача-професіонала.

Як уже зазначалось, вищій рівень структури професійно-педагогічної компетентності викладача військового ВНЗ складають метапредметні компетентності. У сфері професійно-педагогічної діяльності - викладачавійськовослужбовця компонентами розглядуваних ключових компетентностей виступають такі: уміння вчитися, функціональна й інформаційно-комунікаційна. Уміння вчитися являе собою акмеологічну потребу викладача військового ВНЗ в неперервному розвитку педагогічної майстерності шляхом формальної, неформальної та інформальної освіти, уміння самостійно або з допомогою здобувати важливі для життєдіяльності і життєтворчості знання, навички, продуктивні способи виконання професійно-педагогічних завдань, тобто організовувати цілісний неперервний багатофункціональний процес навчання протягом усього життя. Функціональна метакомпетентність передбачає здатність фахівця комплексно використовувати у практичній площині набуті під час вузівського і післядипломного навчання знання та вміння. Інформачійнокомунікаційна метакомпетентність забезпечує медіа-грамотність викладача-військовослужбовця, розвиток його технічних і технологічних знань, використання інформаційно-комунікаційних технологій в освітньому процесі, здатність орієнтуватися у швидкозмінних інформаційних потоках техногенного суспільства, застосовуючи при цьому раціональні прийоми пошуку, аналізу, адекватного відбору, систематизації, використання професійно значущої інформації та створення нової, логічно-узагальненої для оптимізації навчально-виховного процесу тощо. 
Метакомпетентностями у сфері професійно-педагогічного спілкування $\epsilon$ соціальна $\mathrm{i}$ корпоративна компетентності. Соціальна компетентність передбачає усвідомлення викладача військового ВНЗ соціальних проблем і способів взаємодії із суспільством; уміння знаходити інформацію і впевнено конструювати поведінку для досягнення балансу між власними потребами, очікуваннями, сенсом життя і вимогами соціальної дійсності; конкретизацію у свідомості індивіда своїх дій та вчинків. Корпоративна компетентність, включає здатність викладачавійськовослужбовця продуктивно організовувати освітню взаємодію в ході викладання професійно-орієнтованих (спеціальних) та загальних дисциплін в контексті нестандартно-творчого вирішення тих питань, які виходять за межі індивідуального компетентнісного досвіду і є завданнями, зорієнтованими на спільну співпрацю.

Метакомпетентностями в реалізації особистості викладачапрофесіонала $\epsilon$ психологічна, мотиваційна, загальнокультурна. За сформованості психологічної компетентності він здатен адекватно усвідомлювати власний рівень спеціальних педагогічних здібностей, потенційних ресурсів, бачити перспективи і недоліки у своїй роботі та володіти знаннями про дієві засоби вдосконалення педагогічної майстерності в системі військової освіти. Загальнокультурна компетентність передбачає досягнення викладачем-військовослужбовцем високого рівня розвитку в суспільній, виробничій і духовній сферах життєдіяльності. Мотиваційна компетентність включає здатність фахівця до неперервного самовдосконалення, планування шляхів розвитку педагогічної майстерності за індивідуальною освітньою траєкторією.

Нижній рівень ієрархічної структури професійно-педагогічної компетентності викладача-військовослужбовця становлять предметні компетентності. Вони $\epsilon$ частковими щодо окреслених вище метакомпетентностей, оскільки необхідні для кваліфікованого викладання навчальних дисциплін (в тому числі спеціальних), допомагають фахівцю успішно зреалізовувати завдання військової освітньої галузі, виконувати функціональні обов'язки і ролі відповідно до суспільних викликів та оновленої виховної парадигми.

Предметними компетентностями у професійно-педагогічній діяльності викладача-військовослужбовця виступають: спеціальна компетентність у військовій сфері, методична (загальнометодична i функціональнометодична), методологічна, інформаційно-технологічна, компаративна, полікультурна, інтелектуально-педагогічна, креативна, операціональна.

Спеціальна компетентність у військовій сфері $є$ гармонізацією науково-предметних, методичних, дидактичних й педагогічних знань викладача-військовослужбовця для забезпечення якості освіти. Проте знання педагога, за слушним спостереженням I.А. Зязюна, - не сума засвоєних дисциплін, а особистісно усвідомлена система, де $є$ місце власним оцінкам, 
критичним поглядам, і майстерність полягає в «олюднюванні», натхненності знання [7].

Стратегічна мета професійно-педагогічної діяльності викладачавійськовослужбовця полягає в цілісності впровадження компонентів дидактичних систем навчання на засадах інноваційних освітніх підходів i технологій, процесуально-змістовому забезпеченні навчального процесу на принципах галузевості і пробільності від навчально-виховної мети до високого результату. Методична компетентність викладача військового ВНЗ в галузі засобів формування знань, умінь і установок включає засвоєння викладачем-військовослужбовцем нових методичних i педагогічних ідей, освітніх підходів (компетентнісного, особистісно зорієнтованого, комунікативно-діяльнісного, соціокультурного) і технологій (інтерактивних, розвивальних та ін.), володіння інноваційними методами, формами i способами організації навчання. Крім загальнометодичної компетентності, викладач-майстер має оперувати частковими, конкретними методиками зі спеціальних дисциплін.

3 інноваційними ролями дослідника й експериментатора безпосередньо корелює методологічна компетентність викладача-військовослужбовця. Високий рівень його методологічної культури уможливлює здійснення в умовах сучасного військового ВН3 науково-дослідної i пошуковоекспериментальної діяльності, передбачає науковий пошук, розробку, експериментальну перевірку ефективності, життєспроможності нових зразків перспективного педагогічного досвіду у формі способів, прийомів, моделей, положень, авторської методики, системи діяльності. Кінцевим продуктом науково-дослідної роботи викладача-військовослужбовця може стати творчий проект, наукова розробка, методичні рекомендації, науковий звіт про результати дослідження, комп'ютерна презентація про реалізацію положень власної концепції, авторська програма, навчальний посібник тощо.

Інтелектуально-педагогічна компетентність - це професійно значуща якість викладача, що виявляється в умінні застосовувати власний інтелектуальний потенціал для налагодження педагогічно цілеспрямованих взаємовідносин, набуття знань і вироблення способів інноваційної діяльності.

Із інтелектуально-педагогічною безпосередньо корелює полікультурна компетентність викладача-військовослужбовця, що охоплює сукупність знань, пов'язаних із національними і світовими культурно-мистецькими надбаннями, менталітетом, етичними й естетичними цінностями, а також уміння співіснувати і співдіяти в діалозі культур.

Операціональна компетентність як професійно значуща якість фахівця, що визначається набором певних навичок, необхідних для здійснення високорезультативної професійно-педагогічної діяльності.

Творче виконання викладачем професійних обов'язків, спроможність генерувати незвичні інноваційні ідеї, відходити від традиційних схем і поведінкових та змістових шаблонів, діяти оригінально, застосовуючи елементи педагогічної імпровізації, новизни, уможливлює формування креативної компетентності. Загальновідомо, що людина «творчого» типу 
характеризується перетворювальним ставленням до предмета. Тому викладач-військовослужбовець, який володіє високим рівнем креативної компетентності, вирізняється внутрішньою установкою на креативну самореалізацію, прагне до вдосконалення відомих і розробки нових методів, прийомів і форм співробітництва.

Підвидами предметної професійної компетентності у професійнопедагогічному спілкуванні є психолого-педагогічна й управлінська.

Психолого-педагогічна компетентність у сфрері професійнопедагогічного спілкування проявляється в умінні викладача військового ВНЗ проектувати й зреалізовувати на основі діагностики індивідуальну траєкторію розвитку кожної дитини, моделювати засвоєння змісту 3 урахуванням сенситивних періодів вивчення навчального предмета, індивідуальних інтелектуально-психологічних особливостей курсантів й слухачів ВНЗ зі специфічними умовами навчання (задатки, вікові та індивідуальні здібності, інтереси, суб’єктний досвід тощо).

Досягнення професійного i життєвого успіху можливе завдяки гармонійним гуманним стосункам і високому рівню взаємовідносин з усіма суб'єктами навчального процесу. Управлінська компетентність передбачає володіння фахівцем методами, прийомами організації власної професійнопедагогічної діяльності та ефективної навчальної діяльності учнів; управління навчальним процесом на принципах гуманізму та співпраці.

Серед предметних компетентностей, що забезпечують реалізацію особистості викладача-військовослужбовця, виділяємо прогнозувальнорефлексивну, деонтологічну і ціннісно-світоглядну.

Прогнозувально-рефлексивна компетентність включає вміння моделювати індивідуальну освітню траєкторію всебічного розвитку кожного курсанта, якостей, почуттів, поведінки, можливих відхилень на цьому шляху; технологічно грамотно прогнозувати, конструювати, планувати перебіг освітнього процесу; здійснювати контрольно-оцінювальну діяльність, спрямовану на себе й того хто навчається - суб'єкта співпраці; проводити моніторингово-рефлексивні процедури, створюючи на основі отриманих результатів програмно-тематичні комплекси (моделі) планування вивчення всього курсу або теми, або ж окремої лекції, семінарського чи практичного заняття.

Ціннісно-світоглядна компетентність спрямовує викладачавійськовослужбовця на предметному рівні застосовувати знання 3 педагогічної аксіології, що 3 одного боку, формують його професійну i світоглядну позицію, стиль професіонально-педагогічної взаємодії, а 3 іншого - ціннісно-світоглядну позицію вихованців.

Моніторингова компетенція зумовлює володіння викладачем арсеналом засобів відстеження якості і результативності навчально-виховного процесу, рівня особистісного зростання кожного курсанта або слухача.

У нових соціокультурних умовах викладач також має оволодіти системою знань у галузі педагогічної акмеології й деонтології, тобто закономірностями і механізмами морально-особистісного й професійно- 
фахового зростання, методами i прийомами розвитку педагогічної майстерності шляхом самонавчання, самопізнання, самоосвіти, самоконтролю тощо.

Деонтологічна компетентність передбачає властивість особистості викладача-військовослужбовця, що дає йому змогу продуктивно взаємодіяти iз внутрішнім (фаховим) та зовнішнім (соціальним) середовищем завдяки наявності деонтологічних ЗУН, професійно важливих деонтологічних якостей, спрямована на успішну особистісно-фахову діяльність. Вона характеризується наявністю у фахівця системи знань, що відображають змістову сутність інтелектуальних, світоглядних та моральних цінностей; спроможність прогнозувати та конструювати процес професійної діяльності 3 урахуванням іiі специфіки і в площині взаємодії з колегами та відображається в змісті норм професіональної етики, моральними імперативами та професійно-моральними ідеалами й цінностями професійної діяльності. Структура деонтологічної компетентності базується на морально-етичних установках, орієнтирах соціально-професійного середовища та включає мотиваційний, креативний, когнітивний та рефлексивний компоненти.

Висновки. Отже, проблема розвитку педагогічної майстерності викладача вищого військового навчального закладу (ВН3 зі специфічними умовами навчання) полягає у детальному вивченні структури його педагогічної компетентності і відповідно у створенні, розробці й подальшому впровадженню в систему військової освіти механізмів підготовки викладачамайстра - акмепрофесіонала, якому властива самоорганізація і саморозвиток під впливом певних акмеологічних та деонтологічних факторів, умов i ресурсів. Відповідно до перерахованих характеристик компетентним викладачем військового ВНЗ можна вважати того, хто завдяки мобілізованим достатнім знанням, умінням, спеціальним професійним здібностям, особистісним якостям спроможний успішно здійснювати інноваційну професійно-педагогічну діяльність в сучасних соціокультурних умовах. Тобто викладач військового ВНЗ - майстер - це компетентний педагог, знаючий, обізнаний, здатний в умовах військової педагогічної освіти до розвитку педагогічної майстерності за індивідуальною освітньою траєкторією.

Лише за реалізації цих завдань можна говорити про сформованість акмеологічної й деонтологічної компетентностей, готовності і здатності педагога протягом життя бути провідником і моральним взірцем для своїх вихованців - майбутніх захисників України в сучасних складних військовополітичних, морально-етичних та суспільно-економічних умовах.

\section{ЛІТЕРАТУРА}

1. Удосконалення педагогічної майстерності в умовах особистісно-зорієнтованої освіти : модульний посібник / Автори-упорядники: П.І Матвієнко, Н.І. Білик, О.О. Новак. - Полтава: ПОІППО, 2006. - 292 с.

2. Мухлаева T.B. Освоение методологических основ интеграции содержания образования как условие профессионального роста учителя: дисс. ...канд. пед. наук : 13.00.01 / Татьяна Всеволодовна Мухлаева; [РАО ИОВ]. - СПб., 1996. - 221 с. 
3. Закон України «Про вищу освіту» // Урядовий кур'єр. - 2014. -13 серпня. - № 146. - С. $7-18$.

4. Сидоренко B.B. Теоретичні і методичні засади розвитку педагогічної майстерності вчителя української мови і літератури в системі післядипломної освіти: дисс. ...док. пед. наук : 13.00.04/ Вікторія Вікторівна Сидоренко; [РАО ИОВ]. К., 2012. - 421 с.

5. Маркова A.K. Акме в профессиональном развитии человека / Аэлита Капитоновна Маркова / Акмеология : учебник. Изд. 2-е, перераб. / Под общ. ред. А.А. Деркача. - М.: Изд-во РАГС, 2006. - С. 294-305.

6. Метешкін К.О. Інструментальні засоби та механізми їх використання для побудови індивідуальних траєкторій навчання [Електронний ресурс] / Костянтин Олександрович Метешкін, Капіталіна Дмитрівна Гурова. - Режим доступу: www. URL: http://www.nbuv.gov.ua/e-journals/ITZN/em11/content/09mkotei.htm.

7. Педагогічна майстерність : підручник / І.А. Зязюн, Л.В. Крамущенко, І.Ф. Кривонос та ін.; за ред.. І.А. Зязюна. - 3-тє вид., допов. і переробл. - К.: СПД Богданова А.М., 2008. - 376 с.

8. Ягупов В. В. Теорія і методика військового навчання / В. В. Ягупов; Київ. нац. ун-т ім. Т.Шевченка. - К. : Тандем, 2009. - 380 с.

В. Артемов, доктор педагогических наук, доцент

Национальная академия Службы безопасности Украины

В. Сериков, кандидат педагогических наук,

старший научный сотрудник

\section{РАЗВИТИЕ ПЕДАГОГИЧЕСКОГО МАСТЕРСТВА ПРЕПОДАВАТЕЛЯ ВЫСШЕГО УЧЕБНОГО ЗАВЕДЕНИЯ СО СПЕЦИФИЧЕСКИМИ УСЛОВИЯМИ ОБУЧЕНИЯ}

В статье предпринята попытка исследовать проблемы развития педагогического мастерства преподавателя высшего военного учебного заведения со специфическими условиями обучения. Проблема развития педагогического мастерства преподавателя ВУЗА со специфическими условиями обучения заключается в детальном изучении структуры его педагогической компетентности и соответственно в создании, разработке и дальнейшему внедрению в систему военного образования механизмов подготовки преподавателя-мастера акмепрофесіонала, которому свойственна самоорганизация и саморазвитие под влиянием определенных акмеологических и деонтологических факторов, условий и ресурсов.

Ключевые слова: педагогическое мастерство; профессиональная готовность; профессиональная компетентность; метакомпетентність; предметная компетентность; компетентностно-ориентированный подход; кластерньй анализ

V. Artemov, Doctor of Pedagogic Sciences, associate professor

National Academy of Security Service of Ukraine

V. Serikov, Candidate of Pedagogic Sciences,

senior research worker

THE DEVELOPMENT OF PEDAGOGICAL SKILLS OF TEACHERS OF HIGHER EDUCATION INSTITUTIONS WITH SPECIFIC CONDITIONS OF LEARNING

The article attempts to explore the problems of development of pedagogical skill of the teacher of the higher military educational institutions with specific conditions of learning. The problem of development of pedagogical skill of the teacher of higher education institution with specific conditions of the learning lies in the detailed study of the structure of pedagogical competence and, accordingly, in the creation, development and further implementation in the military education system of mechanisms of preparation of the teacher-master, which is characterized by self-organization and self-development under the influence of certain acme logical and deontological factors, conditions and resources.

Key words: teaching skills; professional readiness; professional competence; subject competence; competence-oriented approach; cluster analysis 